Jerzy Kur

Poznan School of Logistics

e-mail: jerzy.kur@wsl.com.pl

Marian Guzek

Lazarski Universiti

e-mail: marian.guzek@wp.pl

\title{
DERIVATIVES AND CRYPTOCURRENCIES AS THE INSTRUMENTS OF NEOLIBERAL POLICY
}

\begin{abstract}
Background: The aim of the paper is an evaluation of the doctrinal foundations of the derivatives and cryptocurrencies as well as their empirical implementation results. The neoliberal policy is based on two elements: a libertarian idea of the minimal state and monetarism of Milton Friedman.

Methods: Comparative analysis of various instruments of monetary policy situated within neoliberal policy context.

Results: Financial assets, even toxic but required by Samuel Konkin's left wing version of libertarian agorism(open market) and his counter-economics ideas.

Conclusions: Cryptocurrencies and derivatives markets' growth exceeds theoretical borders of neoliberal monetary, and even, general economic policy becoming a part of neolibertarian order of world economy.
\end{abstract}

Keywords: Cryptocurrencies, Derivatives as the Instruments of Neoliberal Policy

\section{INTRODUCTION}

In the linguistic sense, the prefix neo- means a newer version of what was. In the economic sense, neoliberalizm means a newer, and implicitly, better version of Adam Smith's liberalism. Because in the history of economics as science has happened so many times, there were already several versions created, called neoliberalism. The primary doctrinal basis of the existing socio-

Kur J., Guzek M., Derivatives and Cryptocurrencies as the Instruments of Neoliberal Policy [in:] Adamczak M. et al., Digitalization of Supply Chains, Spatium, Radom 2019, p. 177-183. https://doi.org/10.17270/B.M.978-83-66017-86-3.13 
political current, called neoliberalism, can be considered as the results of the venture of the famous laisseurist, i.e. the preacher of free market economy rules, Friedrich Hayek. At the end of the 1940s, the international scientific community he organized assumed that it was necessary to counteract the phenomena considered to be dangerous to human civilization: the reduction of the role of the individual for the sake of state power, the depreciation of the principle of private property and the free market, and preventing the emergence of dispersed power as guarantor of full freedom of socjety (Blinder A. S.).

It should be recalled that the defects of the state formulated in this way did not resort to the already known in more distant history, but propaganda allegations that the central government robs society and uses Violetce against individuals. Hayek and his followers meant the scientific form of argument used to reject the classical theory of liberalism and its version refined by J.M. Keynes and P. Samuelson. Already after the first meeting in 1947, Hayek's MPS (Mont Pelerin Society) announced that in the fight against identified threats to Western civilization one can not rely on the classical theory of liberalism. This theory, along with Keynesianism, was replaced in the following years by the Hayek-Friedman doctrine, based on minarchism, i.e. the firststage of libertarianism, in combination with the monetarism of Milton Friedman. The matter became so serious that from the 1980s the implementation of economic and social policy began, according to the model of the New world order, about whichProfessor Immanuel Wallerstein wrote: "Anti-systemic movements - or a family of anti-systemic movements - will confirm the will to transform in specific operational activities capitalist world economy in a worldwide libertarian order that will be egalitarian and fraternal [Guzek, 2019].

The main theses of this paper stem from the claim that the current of thought built on the foundation of minarchism and monetarism, called neoliberalism, has little in common with liberalism. It can be best regarded as its degenerated form. However, this did not prevent the spread of neoliberalizm under the screen as a radical, improved version of classical liberalism. Thus the neoliberale appropriated the name "liberalism", as a result of which opponents of neoliberalism, who were in fact advocates of classical liberalism and Keynesianism, were forced to disseminate the opinion thatliberalism is defective and liberal sarepests. Neo-liberal opponents call them selves conservatives with out clearly defining their links with the classical liberalism from which they were evicted.

Kur J., Guzek M., Derivatives and Cryptocurrencies as the Instruments of Neoliberal Policy [in:] Adamczak M. et al., Digitalization of Supply Chains, Spatium, Radom 2019, p. 177-183.

https://doi.org/10.17270/B.M.978-83-66017-86-3.13 


\section{DERIVATIVES AND CRYPTOCURRENCIES - TOOLS OF NEOLIBERAL POLICY}

The aim of the paper is an evaluation of the doctrinal foundations of the derivatives and cryptocurrencies as well as their empirical implementation results. The neo-liberal policy is based on two elements: a libertarian idea of the minimal state and monetarism of Milton Friedman.

In democratic systems politicians develop the strategy and tactics of accomplishing that doctrine supplemented with more neoliberal elements by Friedrich Hayek.

1. It was from neoliberal ideology, which idolises the free market and fights the state, and has been readily assimilated since the 1980 s by corporations as well as politicians and state officials, that arbitrary activity of investment and commercial banks unsupervised by the state emerged, only to be followed by a capital volcano under the name of derivatives market.

Prior to the financial crisis eruption in 2007, the value of the world derivatives market exceeded 600 trillion dollars. At present it is much bigger. The fact that this market as many as ten times exceeds the annual world GDP is an indication of its sheer size (Knowlton B., 2008).

Although all three main forms of derivatives, i.e. interest-rate, credit and currency derivatives, develop after the outbreak of crisis on this market, it is the second type - namely credit - that can become a particular source of shock, one stronger than before.

2. The derivatives market is associated with generating enormous amounts of credit money as a result of credit operations carried out by commercial banks in line with the “debt breeds money" principle. It was in such conditions that a circulation of enormous virtual dollars emerged, and the world supply of credit money was adjusted to suit the needs of the derivatives market, i.e. assets, even though toxic but required by Samuel Konkin's left wing version of libertarian agorism (open market) and his countereconomics ideas [Koniki, 1980].

Pessimists believe that a next outburst would have to lead to a total collapse of the dollar, and possibly to the collapse of the other world currency, i.e. the euro. What is also interesting is the attitude of economists. The majority of economists would probably feel much better if a terribly huge derivatives market were not referred to at all. They prefer not to mention it, but

Kur J., Guzek M., Derivatives and Cryptocurrencies as the Instruments of Neoliberal Policy [in:] Adamczak M. et al., Digitalization of Supply Chains, Spatium, Radom 2019, p. 177-183.

https://doi.org/10.17270/B.M.978-83-66017-86-3.13 
wishing - for professional reasons - to reveal a minimum of interest in threats to financial markets and they express anxiety about the fortunes of these markets.

3. Some economists show concern with vast reserves of dollars in the world, but find strong reassurance in categorising them as "reserve money", because they do not circulate in commodity markets. However this type of money can be spotted on a peculiar grey capital market in the company of fat rolls of paper which constitute toxic assets, in which money finds a specific backing [Roubini, 2008].

A question is who takes care of the balance between this "backing" and the amount of virtual dollars? First of all it must be the United States that had become the first victim of the ideology of neoliberalism which originated with the Chicago school of economics and its partner, Harvard University, supporting to implement the idea of deregulation of the banking system. The next question is, what can bring about a new explosion?

4. Theoretically speaking, what can be deemed the main causes of a new world crisis are crisis-generating factors present in the neoliberal doctrine, which remains the foundation of economic policies, and application in policy of faulty anti-crisis therapy named austerity which increases dysfunction of the state and degeneration of markets [Guzek, 2019].

As far as the direct cause of crisis outbreak on the derivative market is concerned, in line with several critics of modern-day corporate capitalism, one can predict it will be, first, an imbalance on the grey world financial market, when the supply of credit derivatives will exceed the ability of the market to absorb them without excessive depreciation of the dollar as credit money, and later on the market of the genuine dollar as the world currency due to over excessive depreciation of the dollar.

5. Maintaining further balance on both world markets of the dollar, i.e. grey and genuine until the US manages to rebuild its position of the main monetary power in the world should be enough. An important role in achieving this objective will still be played by the quantitative easing policy. Although it is mainly considered a method of supporting US economic growth, bond redemption carried out as part of the policy, which makes it possible to lower the level of toxic assets on the derivatives market, is even more important. 
If we add to it opportunities for the US to become an energy power, not only self-sufficient in terms of production of gas and oil, but also able to develop significant exports of these materials, which would have an anti-crisis effect, one can conclude that suspecting the USA of an intention to withdraw the dollar from the function of the world, or even national currency, is unconvincing.

More complicated are doctrinal premises of cryptocurrencies.

6. The zero backing of the bitcoin by anything is completely at odds with the Austrian school theory, or even with monetarism of Milton Friedman, who demanded that the size of the central bank's new issues be adjusted to the growth of the national income. The very neoliberal ideology does not explain causes of the cryptocurrencies popularity. More convincing explanation can be found in deeper libertarianism [Sławiński, 2006].

Influenced by the present world crisis, certain eminent libertarians expressed critical opinions about the Chicago school of economics, which - together with representatives of Harvard University associated with it - was blamed for excessive deregulation of the banking sector and outbreak of financial crisis. As the real 21st-century world is transformed and complemented by the virtual world promulgated by the internet, we can observe occurrence of phenomena, which once would have been deemed preposterous.

7. The present form of libertarianism, which is shaped by the Austrian school, approves of a global currency in the form of bitcoin and other similar forms of virtual money, so that they can compete with each other. Thus, an attempt to seriously modify the Austrian school's monetary theory is taking place. The officially tolerated presence of the cryptocurrencies in circulation over the world can be accounted for in that the edge of this "money" is aimed directly at replacement of the genuine currencies [Guzek, 2019].

The significance of the seemingly nonsensical threat from the non-money to the global currency market reveals itself. Tolerating such "money" by the leading powers can be explaned with the minimal state rule, requiring a sufficient level of helplessness even of the powers. One of the most radical Polish libertarians has let slip the ultimate aim of introducing massive amounts of cryptocurrencies all over the world:

Kur J., Guzek M., Derivatives and Cryptocurrencies as the Instruments of Neoliberal Policy [in:] Adamczak M. et al., Digitalization of Supply Chains, Spatium, Radom 2019, p. 177-183. https://doi.org/10.17270/B.M.978-83-66017-86-3.13 
8. "Making use of cryptocurrencies is fast and safe. We don't pay any commission and conversion fee. Except that cryptocurrencies make the traditional money as well as the central banks - and even any bank in general - redundant"1.

However, recent opinions of some scientists predict a collapse of cryptocurrencies. Professor Nouriel Roubini in his interview given in Poland was asked about the bitcoin.

Roubini's viewpoint: "First of all, I would separate the blockchain from the bitcoin. Blockchain creates an enormous chance to increase productivity in many companies and I think the technology to be something very good. But the bitcoin and other cryptocurrencies - this is something entirely different. In my opinion, there is a gigantic speculative bubble related to the bitcoin, because this is neither a serious method of payment nor a good way to store capital. The bitcoin feeds on itself. There are no fundamental reasons for its price to reach such levels. What's more - it is also used by criminals, for their shady business. I think that more and more countries will start to make cryptocurrency exchanges illegal like China did. New regulations will be adopted. So, this will find its end"2 . Let us hope that Professor Roubini's expectations will be fullfield soon.

\section{CONCLUSIONS}

The following economics in transformation sinclude the most important doctrinal projects of neoliberalism:

1) conversion of classic and Keynesian dem and economics into supply economics [Haberler, 1985].

2) rejection of Keynes's investment multiplier theory.

3) replacement in the Fisher Irving model of the explanatory variable in the form of the number of transactions with the size of national income as the basis for determining the size of the Money issue.

4) inclusion of Lucas' national expectations hypothesis in economic theory [Roberts, 2013].

\footnotetext{
${ }^{1}$ Stodolak S., „Pieniądz bezpaństwowy” ('The Stateless Money’). „Dziennik Gazeta Prawna” ('Daily Law Journal'), Warsaw, 20 October 2017.

2 businessinsider.com.pl
} 
Each of these transformations serves the main purpose of libertarian philosophy in its first stage, i.e. minarchism, in the form of a "minimalstate". If the state can influence demand, and supply is determined by entrepreneurs, let demand be excluded from the economy as a field for the state to act. Depriving the government of the ability to achieve a multiplier effect as a means of preventing recession is to help remove the state from the economy

and crisis and stimulating economic growth. Private banks are expected to help remove the state central bank or at east replace it. They make a significant part of the annual currency issuance in the form of credit money, especially when the increase in national income is insignificant, but market transactions served by private banks can be large, conducive to the principle of "credit gives money".

And finally, everyone in socjety needs to be convinced that it is the free market that all actors act rationally, so the states hould not disturb them with its interventionism.

\section{REFERENCES}

Blinder A. S., „What's the Matter with Economics? An Exchange”. The New York Review of Books. Www.nybooks.com

Boillier D. „The Commons as a Rising Alternative to State and Market”. Huff Post Business, 28.10.2014.

Guzek M., Nowy Porządek Świata - Dekompozycja państw i narodów. Oficyna Wydawnicza Uczelni Łazarskiego, Warszawa 2019.

Haberler G., Mr. Keynes's Theory of the "Multiplier": A Methodological Criticism, [w:] Selected Essays of Gottfriend Haberler, MIT Press, Cambridge 1985.

Knowlton B. , Grynbaum M. M. , „Greenspan `shocked` that free markets are flawed”, The New York Times, October 23, 2008.

Konkin S., New Libertarian Manifesto, Anarchosamisdat Press, 1980.

Roberts P. C., The Failure of Laissez Faire Capitalism and Economic Dissolution of the West. Clarity Press, Atlanta 2013,

Roubini N., Crissis Economics: Crisis Economics: A Crash Course in the Future of Finance, 2008.

Sławiński A. Rynki finansowe, Warszawa 2006.

Kur J., Guzek M., Derivatives and Cryptocurrencies as the Instruments of Neoliberal Policy [in:] Adamczak M. et al., Digitalization of Supply Chains, Spatium, Radom 2019, p. 177-183. https://doi.org/10.17270/B.M.978-83-66017-86-3.13 



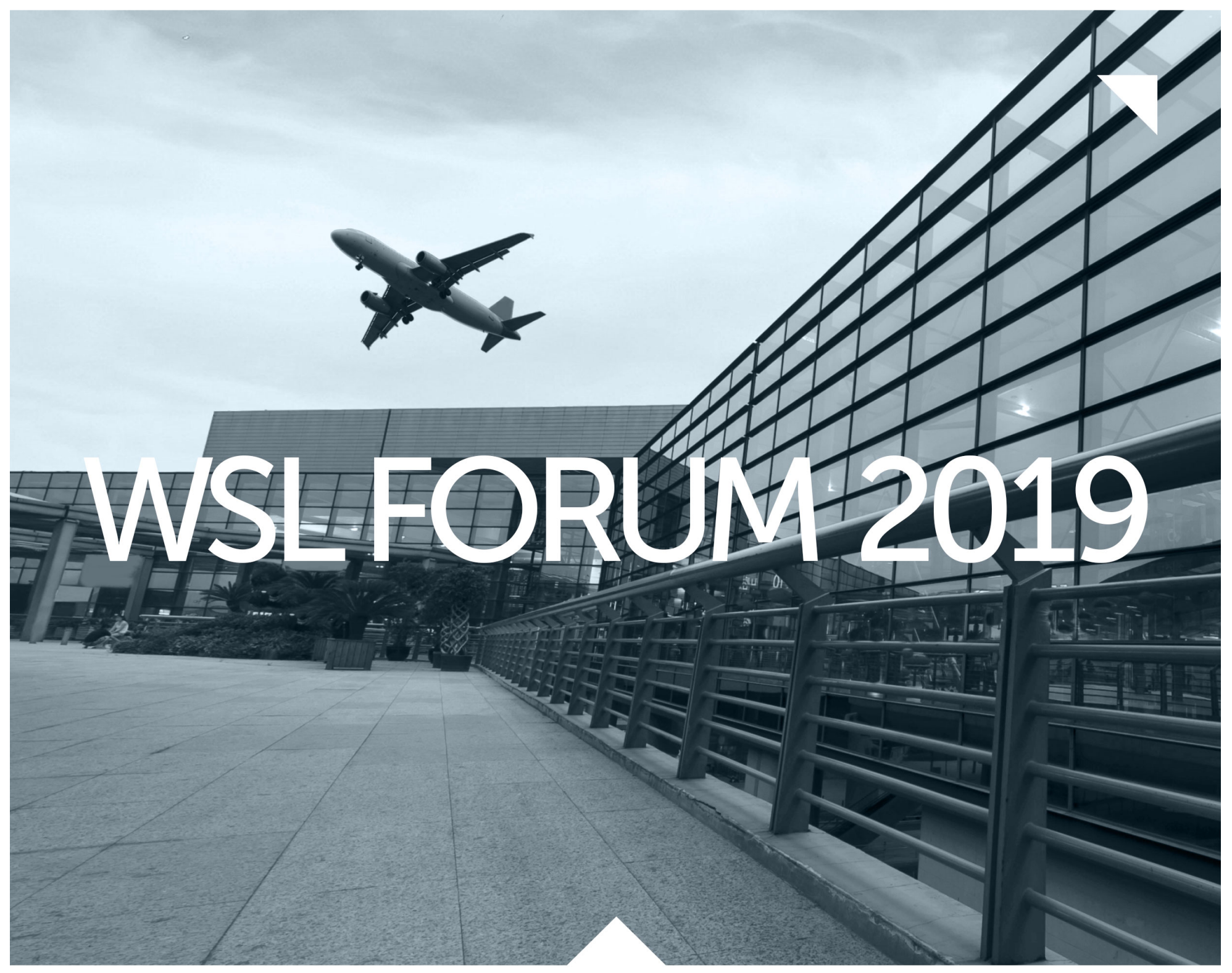

Papers included in this monograph was presented during WSLFORUM 2019 conference 18th - 19th of November 2019 in Poznan School of Logistics.
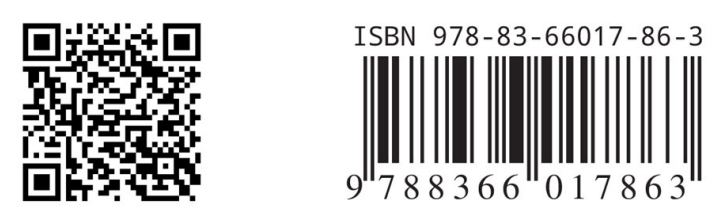